\title{
CROATIAN-HUNGARIAN TRANS-BORDER RELATIONSHIPS FROM STATE SOCIALISM UNTIL TODAY, WITH SPECIAL ATTENTION TO THE EUROREGIONS
}

\author{
Lóránt Bali PhD aspirant, \\ geographer, PTE-TTK Geographical Studies, Doctoral Programme
}

\section{Summary}

On the whole we can claim that in the last almost sixty years there was a significant change in Croatian-Hungarian trans-border relationships. State-governed cooperation was replaced by project-controlled co-operations under the guidance of local-governments and the civil sphere. Unfortunately, stock and human workforce deficit very often obstructs success. Besides it is a permanent problem in our country that state politics has a great influence on local-government politics. So in a certain euroregion the success of operation highly depends on where the local-governments and civil organization belong to politically and on the leaders' ability to validate their interests. As a result of stock deficit mentioned previously project-based co-operations occurred.' But these ad hoc project associations are not able and won't even be able to use union sources efficiently and generate any kind of long-term regional development.

\section{The situation of the Croatian-Hungarian border between the period of the Austro- Hungarian Compromise and state socialism}

The 1868. Compromise law has already disposed of the Croatian-Hungarian border. It declared that "Hungary, Croatia, Slavonia and Dalmatia are parts of one and the same state community...." "The state area is uniform, only Hungary has own borders, the border between Hungary and its partner states is only administrative."2 This situation remained until the Trianon Peace Treaty. As a result of the peace treaty - putting an end to World War I. the administratively separate Croatia-Slavonia became a part of the SZHSZ Kingdom. The new border-line - which didn't impeded the social-economic relationships significantly - was appointed along the Dráva and the one-time interstate administrative border with several small corrections. ${ }^{3}$ In spite of the seemingly intensive economic relationships the first signs of separation were already present. In April 1941. with the support of Germany we retrieved Muraköz and the Baranya-triangle. But the Paris Peace Treaty that put an end to the war unfortunately set back the Trianon situation in $1947^{4}$.

\section{Trans-border relationships and their nature in the Croatian-Hungarian border area during state socialism}

The short democratic period that followed World War II. was too short to set in motion the trans-border cooperation between the two states. From 1949. on the bilateral relationships perished ${ }^{5}$, in the 1950 s the permeability of the $621 \mathrm{~km}$ long Yugoslav ${ }^{6}$ Hungarian border disappeared almost completely and became the field of open military and political confrontation. In the summer of 1951. redoubt work started. A $430 \mathrm{~km}$ long protection zone was established which was strengthened by minefields, barbed-wire fences and concrete fortresses. ${ }^{7}$

From the end of the 50s relief occurred between the countries of the socialist block and the "separate passenger" Yugoslavia. It made possible that trans-border relationships 
quickened again from the middle of the $60 \mathrm{~s}$. We differentiate between two types from the point of view of the two states, the locally and centrally organized ones. In order to improve cooperation several centrally organized fact-revealing and proposal-making courses took place.

To control complex proposal-making work, in 1969. the Hungarian-Yugoslav Urban and Town planning Constant Vice-committee was established to examine the HungarianYugoslav borderline, work out and harmonize development conceptions. Working out the tourist-holiday regional development plan of the Örség-Lendvai Wold together with the Slovene Environmental and Town planning Committee and the Geographical Institution of Ljubljana University was among the tasks suggested by the vice-committee. The expansion conception of the Danube Region and the preparation of impact assessments about the water power-stations set up on the Dráva and Mura happened in cooperation with the Eszék Urban Institution. ${ }^{8}$ One of the most important problems of the Yugoslav-Hungarian borderline was the common environmentally sound use of the Dráva and Mura during the socialist period. In 1978. under an interstate agreement proposals were made in order to solve these difficulties. Concrete and tangible arrangements have already been born before institutionalized interstate planning, for example the delivery of the Gyékényes railway bridge in April 1960.

As we have seen before the Yugoslav-Hungarian relation started to get back to normal only in the 1960s, which made possible the unfolding of bottom-up trans-border relationships. László Gulyás differentiates four dimensions from this perspective: ${ }^{9}$

I. In the 70 s the configuration of official relationships between cross-border counties and cities started. As a result of the federative nature of Yugoslavia, different types of relationships occurred along certain parts of the common borderline. Along the CroatianHungarian part inter-town relationships were dominant such was the establishment of the twin-city relationship between Eszék and Pécs in 1973. which still has a function today.

II. Agricultural relationships gradually came into existence as well. The collective farms around Mohács made an international sugar manufacture verticum with the sugar manufactures in Beli manastir, Bellye and Zupanija. Cooperation was based on comparative advantages. Hungarian big mills exceeded the Yugoslavian partner by right of their produce, but the neighbouring sugar manufactures equipped with German technology were more productive than Hungarian processing industry in their sugar export.

III. From the $60 \mathrm{~s}$ on bilateral shopping tourism started, which turned into curativetourism in several towns in our midst. ${ }^{10}$ In Hungary Nagykanizsa, Nagyatád, Kaposvár, Pécs in Croatia Cakovec, Koprivnica, Virovitica and Osijek were the targets of consumers. Shopping tourism of the given decades can be characterized by different "product baskets" II on both sides. For Hungarian citizens Yugoslavia was an opened door to the West where they could reach a number of services that were unavailable or prohibited in socialist states.

IV. As a result of economic instability Yugoslav citizens, mainly those in the Vajdaság, put their money in Hungarian banks in the 80s. In the 90 s this deposit served as a basis of Croatian and Serb enterprises founded in our country.

\section{The nature of relationships in the $1990 \mathrm{~s}$}

In 1992. during the explosion of the patriotic war after the shouting out of Croatian independence, Hungarian state and local-government leaders, and the actors of the economical sphere had to face an entirely new situation. Along the southern borderline operations and warlike actions were going on often accompanied by border insults. The population and the local-governments of the southerm border had to face and solve new phenomena that they didn't experience at all in the last 45 years as a result of the war. Such was the housing and taking care of thousands of refugees. Hungary not taking with a grain of 
salt - independent from any ethnic and religious views - welcomed and took care of refugees arriving into our country. The greatest sacrifices from this aspect were made by Nagyatád, Kaposvár, Pécs and Siklós.

With the evolving of the war economical relationships were confined to satisfy deficit economy in retail trade, which manifested itself in multitudinous shopping tourism. The target towns of Croatian citizens arriving into our country were Nagykanizsa, Letenye, Nagyatád, Barcs, Csurgó, Berzence, Sellye, Siklós and Mohács. In the settlements of the southern borderline Croatian words occurred everyday, trade became almost unidirectional at the border crossing points.

After peace was restored in Croatia, relationships that once operated but splitted up because of the war had to be restarted again. The inception was equal with laying down the principles everything had to be built from zero. Besides this the configuration of market economy started in Croatia and Hungary at the same time. Both states were still getting to know the new social-economic system. This brought about serious difficulties and was further aggravated, because one-third of Croatia was under occupation, moreover most of the crossborder Slavonia was an area of military action blocked away from any kind of economic circulation.

In the above mentioned period our economic relationships with Croatia were developing relatively slowly. As for me the reasons can be explained by the exaggerated distance keeping and conservatism of economic participants, especially from the Hungarian part. In spite of its situation after the regime change Hungary did its best in favour of the development of trans-border relationships. After 1995. a new chapter started, except for the Baranya-triangle ${ }^{12}$ crossing the border was not problematic, and from 2001. on a free-trade agreement helped to improve our economic relationships.

\section{Some social-economic aspects of the problems of developing trans-border Croatian- Hungarian cooperation}

The Hungarian side of the $355 \mathrm{~km}$ long Croatian-Hungarian borderline is an area struggling economic depression. Among the three counties ${ }^{13}$ concerned in the cooperation Somogy and Baranya belongs to those of loose texture. As a result in the region "cross-border affection" "only predominates weakly". 14

The border area is urbanized weakly and although Nagykanizsa with its 50 thousand citizens is the only town owning significant economic potential, it has surprisingly infirm Croatian relationships. We should mention Mohács as well with its 20 thousand inhabitants, which - due to its border-harbour on the Danube and the sokac ${ }^{15}$ ethnic group - owns many appreciable and unexploited possibilities. Based on the experience of about 15 years, Barcs and Siklós with nearly 10 thousand inhabitants could only benefited from the periodically intensive shopping tourism. The cooperative competences of smaller settlements are confined only to cultural cooperation.

In the region the rate of unemployment is higher than $20 \%$ and its employment level is under $50 \%$ which is significantly lower than the $62 \%$ average rate in the EU. ${ }^{16}$ The situation is the worst in the Siklós small region in Baranya, the best is in Letenye (Zala county), where the average rate of unemployment is around 5\%. Remarkable backwardness can be seen in the field of education. In certain settlements in the Sellye and Siklós small regions the number of finished classes ${ }^{17}$ is under $8,5^{18}$. Besides this Baranya and Somogy possess a large gipsy population, where the above mentioned problems occur cumulatively. The segregation of the gipsy population is accelerated nowadays in Hungary. As a result of their reproduction habits a significant population increase is expected on the middle-term in villages along the Dráva. 
Besides traffic geographical disadvantages are also notable occurring most strongly along the Dráva. The V/B and V/C corridor ${ }^{19}$ doesn't open up the area, the M7 and M6 highway only scrubs it from a western and eastern direction. The situation is even worse on the Croatian side, because the whole highway was built only in the direction of the sea-shore, Belgrád and along the Száva. ${ }^{20}$

Micro-regional relationships are more difficult as a result of the small consistency of the highway border-crossing points. Along the $355 \mathrm{~km}$ there are only six highway and three railway crossing points, out of this there is only one highway bridge at Barcs and one railway bridge at Gyékényes along the $166 \mathrm{~km}$ long river part. Between Drávaszabolcs and Barcs there is a $70 \mathrm{~km}$ long section where it is not possible to cross the border anyhow. So as a result of the rare existence of public road and railway matchpoints the border part of Baranya and Somogy has to face serious traffic drawback. ${ }^{21}$

With modernizing the traditional elements of the traffic network the closeness of this peripheral area could be improved. The Zaláta-bridge being destroyed during World War II. should be rebuilt and route 67 should be lengthened along the Szigetvár-Sellye-Révfalu line until the border. ${ }^{22}$ The construction of a bridge planned to connect Murakeresztúr and Kotoriba would strengthen the micro-regional relationships of Southern-Zala trending towards Croatia. From the point of view of the railway only the Budapest-NagykanizsaMurakeresztúr and the Budapest-Pécs-Magyarbóly lines have real chances for reconstruction. Hungarian railway politics today is rather cutback than development oriented.

\section{Euroregional organizations as possible tools for Croatian-Hungarian transborder co-operations}

At the turn of the second millennium euroregional co-operations live their renaissance in Hungary. They came into being first along the Austrian, Slovene and Slovak border then along the Romanian, Croatian and Serb border. ${ }^{23}$ At first the actors of local-governments and urban intervention assigned too much importance to regional co-operations as efficient stimulus of economy, in several cases they overestimated the possibilities. By today it has been proven true that regional cooperation can be used well as a tool for urban innovation, but its role as a catalyst without any appropriate social-economic potential is relatively low. That is why they tend to operate with different efficacy along the Croatian-Hungarian borderline. But before describing in detail the euroregions along the Croatian-Hungarian border, it is worth mentioning the Alps-Adria Association, which is considered to be the forerunner of euroregional cooperation in Hungary. Zala, Somogy and Baranya - three Hungarian counties next to the Croatian-Hungarian border - joined the 30 year old association founded in 1978 only at the beginning of the regime change. During this period members of the association considered the deepening of cooperation between regions and states to be the primary task. It is proven by the Bled Resolution (1987.) and the Millstadt Declaration (1988.). "Due to Europe's results in this area above different cultures, languages and political systems our governments are willing to support and inspire the cooperation henceforward between regions going on in the Alps-Adria Association that makes an effort to open up borders, gives chance to the free flow of people and ideas and realizes economic and cultural cooperation."24 After the democratization of the area the new goal was the idea of subsidiarity and the realization of social-economic cohesion." "All barriers causing unequality and imbalance had to be removed immediately." 26 By the turn of the century the members had to participate in realizing a new aim, which was supporting the EU integration of Hungary and Slovenia. Nowadays it gives remarkable intellectual capacity to Croatia to get to know the laws of the European Union hereby it helps the successful and quick outcome of connection discussions. 
In 2007. the reforming of procedural and organizational rules of the Alps-Adria Association took place in Klagenfurt aiming to deepen and dinamize cooperation. Today on behalf of Baranya stronger and stronger languidity can be seen and the idea of secession has already occurred as well.

On the whole we can claim that the association reached the biggest success in achieving political aims. From an economic point of view no remarkable trans-border success took place. In the future the association had better engage only in projects that are convergent with EU targets. It could be advanced by boosting information-flow and by a more intensive colloquy extended to mezzo-and micro-regional levels in order to deepen cooperation. Besides the Alps-Adria can contribute to the elimination of the democratic deficit that exists between Europe and its citizens in the Middle-Europen area.

The idea of giving birth to a euroregional cooperation aiming to serve the dinamization of Croatian-Hungarian trans-border cooperation was born amongst localgovernment leaders after the regime change. In order to satisfy the needs of economy and urban innovation the chambers of trade and commerce as well latched on to the cooperation between regional and town communes. ${ }^{27}$ Besides the Croatian and Hungarian partners they called in the Bosnian Tuzla commune. As a result an area came into existence with a higher economic and trade potential.

Thus in 1998. the Duna-Dráva-Száva Euroregional Cooperation was born with members sharing common historical and cultural traditions, along the same interests. The fact that on the West-Balkan there was peace and the need for EU integration occurring among the foreign policy aims of post- Yugoslavian states played an important role in its coming into being. But after the foundation the initial impetus stopped. Why? The founding members of the "euroregion" Baranya county, Pécs-Baranya Chamber of Trade and Commerce (Hungary), Osječko-Baranjska county, Osijek city, Croatian Chamber of Economy, the Chamber of Economy of Osječko-Baranjska county (Croatia), Tuzla-Drina Commune, Tuzla city, the Chamber of Economy of Tuzla Region (Bosnia-Hercegovina) were not the members of the European Union yet. The organization included members struggling with stock deficit needed for innovations and investments. Moreover Croatia and Bosnia-Hercegovina had to solve restoration after the civil war.

In the 2000-2006 budget period the EU financial supports materialized within the confines of the INTERREG public initiation in point of cross-border and trans-national cooperation. In the case of Croatia and Hungary certain sources were available only within the confines of experimental small projects in 2004-2006. In the 2007-2013 planning period subsidies can be called down with the help of the IPA in order to deepen cooperation. Baranya and on the Croatian side Eszék-Baranya too are amongst the beneficiary counties. Cooperation can be catalyzed by the fact that in 2010. Pécs - the seat of Baranya-county will be the cultural capital of Europe.

In view of the social-economic situation described in the previous chapter we might raise the question: what possibilities could an area like the southern part of Baranya have where the whole society is socially disadvantaged and ethnically segregated? Finding a solution to problems existing on both sides and further thinking about the small number of innovation and development possibilities could serve as a basis to improve cooperation. As both areas have a serious stock deficit it is worth paying attention to Union support possibilities when defining priorities.

In favour of enlarging the efficiency of bilateral relationships they were trying to establish euroregions that cover smaller areas. Each of these was organized by Zala-county or with the initiation of towns within the county. Along the Croatian-Hungarian borderline the social-economic environment is most ideal in Zala, disadvantages coming from the peripheral situation in the last 15 years could be best liquidated here. Koprivnicko-Križevačka, 
Medimurska and Varaždinska county are affected in the cooperation they represent an economically and industrial strong medium level, moreover the majority of CroatianHungarian international trade passes through there, through the V/B corridor in the direction of Rijeka and Venezia. Besides the closeness of Zagreb (1,5 hour distance) is not negligible either.

The first such initiative that was proven to be dead was the Dráva-Mura Euroregion. The founders of the initiation were Csurgó, Marcali, Nagyatád, Nagykanizsa, Letenye, Lenti, Zalakaros, the Slovene Lendava and the Croatian Varaždin. From the content we can see that the members were inspired to help the cooperation and the innovation of the CroatianSlovene-Hungarian tripartite border. In connection with the organizational construction several ideas occurred. The idea of the small region-based ${ }^{28}$ euroregion was rejected, because such a formation doesn't even exist either in Croatia or in Slovenia. The county-based construction was rejected too, because of the Hungarian administrative regulation. ${ }^{29}$ Finally the "city-idea" won. This way it became possible that cities and settlements of small regions around them could be participants of the organization as well. The above mentioned towns signed a manifestation of will September $9^{\text {th }} 2000$. about founding the Dráva-Mura Euroregion, this was then followed by the signing of the skeleton agreement from the Hungarian part September $14^{\text {th }} 2001$. to which only Lendava joined among the foreign partners December $21^{\text {st }}$. The entry of the association in the commercial register took place in June $21^{\text {st }} 2002$. $^{30}$

The organization in the shape of a public company started its operation with great impetus and hope. This is shown by the fact that Nagykanizsa as a founder member separated 2 million HUF in order to establish the association and support experts with the first steps. Behind there were unconcealed prestige aims, because this way the town became the seat of an international organization.

The initial dynamism was followed by a period of failure and stagnation. The minimizing of functional costs and other financial conditions took place. But these arrangements were proven to be inefficient. The greatest problem was caused by the members' inability in multilateral co-operation, plus the decline of interest turning into negligence. Characteristically two-two towns are able to work together in carrying out a project or handing in tenders, but no extensive program, initiation was born so far. The lowlevel involvement on the part of other members is not a guarantee for constant, medium-term planning at all. ${ }^{31}$ In view of this it is not surprising that the liquidation of the association started in September 2005. further tasks were devolved to the Competition Office and the Mayor Cabinet. Since then there are attempts to restart but without any remarkable results.

As a result of another previously disapproved conception the Mura-Dráva Euroregion was established. During the foundation process Hungarian interest was more significant. In order to eliminate difficulties with the Dráva-Mura Euroregion founders thought it would be better if cooperation would be under the control of regional administrative units (counties). In 2004. coordination of cross border cooperation was undertaken by the office of the Zala County Assembly. In October 2004. the Mura-Dráva Euroregion was established in Cakovec. The members: Medimurska county, Zala and Somogy county. In the meantime Somogy quitted the cooperation. The organization is on the right way to strengthen the socialeconomic cohesion of the area. It is proven by the fact that between 2004-2006. under the INTERREG III.A Slovenia-Hungary-Croatia Neighbourhood Program they were successful in numerous tenders. The permission and financial support of a public road bridge between Murakeresztúr and Kotoriba was the most important amongst all. According to the local hopes if the public road-river bridge is built as soon as possible it will play an important role in amending the accessibility of Croatian-Hungarian neighbouring micro-regions. A touristic project entitled "Down to Mura on the Kerka" was also proved to be very successful. From 
2007 on the euroregion considers the operation of the partner-network and an innovation strategy coordinated in common with Hungarian and Croatian partners as its most important function. ${ }^{32}$

The situation of the "Muránia Euroregion" is significantly different from the previous ones. While in previous cases we were talking about middle-sized towns then in the case of "Muránia" euroregion it is not true. Here each settlement owning economic potential and the legal status of a town can be grouped into the category of a hick town with the best intent.

Region-building started with a project-oriented strategy. The organization slowly fills its fifth year. On the basis of the project-description we can see that innovation of tourism is among the primary priorities of the cooperation. In favour of common promotion and marketing an integrated network of tourist products should be built, plus a tourist-zone should be made in cross-border regions in order to improve common innovative tourist products. The recognizability of the area could be boosted by establishing the common MURANIA Tourist Zone in cross-border regions. Other aims are: building innovative and affective tourist products from a qualitative and market point of view by applying the natural and cultural heritage of the multicultural region; the common promotion of the integrated tourist product; stimulation of tourist enterprises; organizing visits giving information in connection with the tourist zone; increasing the number of tourists. ${ }^{33}$

At present the Slovene Lendava on the Hungarian side Letenye and Lenti are the members of the cooperation. In the 2007-2013 budgetary period from the available IPA sources Croatian areas can also be involved in the cooperation. In the euroregion there is already an intent for that. It would be expedient to get the Croatian Mursko Središce involved in the cooperation. In other words there would be an association on the Croatian-HungarianSlovene tripartite border along the Mura that owns a notable historical-economic cohesion.

Lenti, Lendava and Mursko Središce have the most opportunities in deepening their social-economic relationships. Each town is the centre of only a crossborder micro-region with limited central functions and is in a peripheral situation and, moreover from a traffic point of view they show "blind" signs. In the case of Lenti it is manifested in the form of a railway going nowhere, while Lendva is the end of a railway line arriving from Mursko Središće. Public road traffic shows a paradox picture. In spite of the underdevelopedness of the road-system it is still forced to transact the majority of transit traffic from Austria towards the sea. From the point of view euroregional innovation the restructuring of the road-system is indispensable, by limiting transit traffic and reparing modern railway-connection. At this point we must think it over whether it is worth expanding cooperation by even accepting the change of image. Investments needed to advance cohesion are far beyond the power of the above mentioned villages. It would be worth making a "sectoral" cooperation with the Croatian Čakovec and Varaždin, Nagykanizsa (Zala county), Koprivnica (Croatia) that can not be left out of the list and finally Zalaegerszeg. But this could only be realized with wellmade steps. In a cooperation configured by exploiting comparative advantages "Muránia" could preserve its "Harmony of Existence" atmosphere and besides its ideas about necessary traffic innovation could predominate on a state level. The heavy traffic of Lenti and its neighbourhood can be remarkably reduced by establishing the Zalaegerszeg-Lenti-LendavaCakovec clearway connection. It raises the question that after such a project what justification could a Nagykanizsa-Cakovec-Lenti-Zalaegerszeg "euroregional" train get that would bring the burgenland area even closer. It would find priority from the point of view of all EU aims.

\footnotetext{
Endnotes

1 "Pannon-Palette" the common tourist and cultural project of Kaposvár and Koprivnica. For the more than 58 million HUF worth program the majority of support was won in EU tenders by the participants.
} 
${ }^{2}$ Hajdú Z. 2001: Magyarország közigazgatási földrajza. (Adminstrative geography of Hungary) Dialóg Campus. Budapest-Pécs, pp.39.

${ }^{3}$ After the Trianon border changes Hungarian and Croatian landholders owned land and private property in the neighbouring state.

${ }^{4}$ Romsics I. 2001: Magyarország Története a XX. században (The history of Hungary in the XX: century.) Osiris. Budapest, pp. 668.

'The Soviet Union rejected Yugoslav confederational attempts on the Balkan. As a result of the tension the Kominform convicted Tito in Bukarest, June $21^{\text {st }} 1948$. who has already been considered as an imperialist spy in 1949. Due to the previous actions Hungary dissolved its 5 year economic agreement with Yugoslavia in June 1949.

${ }^{6}$ December $1^{\text {s }} 1918$. the Serbian-Croatian-Slovene Kingdom was shouted out which was carrying the name the Kingdom of Yugoslavia. Between January $31^{\text {s }}$ 1946.and April $28^{\text {th }} 1992$. it was Yugoslavian Socialist Federal Republic.

' Hajdú Z. 2008: A magyar-jugoszláv kapcsolatok a hidegháború időszakában (1948-1955) In.: A baranyai államhatár a XX. Században. HM Hadtörténeti Intézet és Múzeum (Hungarian-Yugoslav relationships during the period of the Cold War (1948-1955) In.: The Baranya state-border in the XX: century. HM Museum and Insititution of Military History.) Pécs, pp. 69-77.; Gulyás L. 2002: A magyar-osztrák és a magyar jugoszláv határ szerepe az államszocializmus időszakában 1948-1990. (The role of Hungarian-Alustrian and Hungarian- Yugoslav borders 1948-1990.) Konferencia-CD. Veszprémi Egyetem Georgikon Mezőgazdaságtudományi Kar. Keszthely.

${ }^{8}$ Zala Gy. 1988: A határmenti együttmũködés szükségessége, eddigi föbb eredményei és problémái. In.: Erdõsi F. és Tóth J. (szerk.) A sajátos helyzetủ térségek terület- és településfejlesztési problémái A Ts-2/2 program iroda (The necessity of trans-border cooperation its main results and problems. In.: Erdősi F. and Tóth J. (comp.) Urban- and region innovation problems of an area with special situation, A Ts-2/2 Office)

${ }^{9}$ Gulyás L. 2005: Két régió - Felvidék és Vajdaság - sorsa az Osztrák-Magyar Monarchiától napjainkig. Hazai Térségfejlesztõ Rt. Hn. (The destiny of two regions - Felvidék and Vajdaság from the Austro-Hungarian Monarch until today. Inland Region Planning Public Company Hn.) pp. 233.

${ }^{10}$ Harkány, Nagyatád, Siklós.

"In the 70 s and 80 s Hungarian customers travelled to Yugoslavia to buy "western" products, mainly clothes and high quality electric goods (eg. Gorenje: refrigerator). In the $80 \mathrm{~s}$ as a result of the increasing inflation Yugoslav citizens came to Hungary to buy food.

${ }^{12}$ Based on the Erdöd Agreement signed in 1995. the Baranya-triangle got back its independence January 15th 1998. until then it was under Serbian control. During this period the Drávaszabolcs public road crossing-point and the Magyarbóly railway crossing-point was not operating at all.

${ }^{13}$ Zala, Somogy, Baranya county.

${ }^{14}$ Golobics P. - Merza P. 2002: Polarizálódó világgazdaság- Nemzetközi Együttmüködés. Pécsi Tudományegyetem, (Polarization of world-economy - international cooperation. University of Pécs) Pécs, pp. 205.

${ }^{15}$ Croatian ethnic group in Baranya county.

${ }^{16}$ Dél-Dunántúl. A kistérségek társadalmi, gazdasági helyzete. Központi Statisztikai Hivatal (South Transdanubium. The social and economic situation of small regions. Central Statistics Office) 2006.

${ }^{17}$ Today in Hungary school-age is 18 . Primary education is in an 8-class system and lasts until the age of 14.

${ }^{18}$ Hajdú Z. (comp.) 2006: Dél-Dunántúl. Dialóg Campus Kiadó (South Transdanubium). Dialóg Campus. Pécs-Budapest pp. 499.

${ }^{19}$ The V/B corridor comes from Budapest through Nagykanizsa in the direction of Letenye and Zagreb; the V/C corridor from Budapest in the direction of Szekszárd, Mohács, Osijek.

${ }^{20}$ Erdősi F. 2005: Magyarország közlekedési és távközlési földrajza (Geography of traffic and telecommunication in Hungary) Dialóg Campus. Pécs-Budapest, pp. 504.

${ }^{21}$ On average there is one crossing point in every $50 \mathrm{~km}$ along the Croatian-Hungarian borderline.

${ }^{22}$ Pirisi G. 2003: A Dél-Dunántúli Régió határ menti kistérségeinek közlekedési problémái. (Traffic problems of cross-border small regions in the South Transdanubian Region) In.: Határok és az Európai Unió. SZTE TTK Gazdaság- és társadalomföldrajz Tanszék. pp. 162-168. 
${ }^{23}$ Let see for example Gulyás L 2004: A Duna-Körös-Maros-Tisza Eurorégió rövid története 19972004. (Short history of DKMT euroregion). Múzeumi Kutatások Csongrád Megyében. 2004. évi Évkönyv. 5-14. old. Szeged. 2004.

${ }^{24}$ Alpok-Adria Munkaközösség. Jövőkép a 21. századi Európában (Alps-Adria Association. Future image in the 21. century Europe), pp.21.

${ }^{25}$ Hungarian members: Baranya, Somogy, Zala and Vas county, Austrian members. Käranten and Burgenland; Italian members: Friuli-Venezia Giulia, Trention-Southern Tirol and Venice; Croatia and Slovenia

${ }^{26} \mathrm{http} / /$ www.alpeadria.org/magyar/files/Chronology1978-2004.pdf Date of download: 08. 13. 2008.

${ }^{27}$ It is a public body owning a local-government established by the actors of economic life in Hungary dealing with the innovation and support of economy, regional development by law authorization.

${ }^{28}$ According to the present constitution in Hungary there are the following administrative levels: parish, county, city, capital. In socialism the county was was the trustee of regional administration and innovation. This was changed during the regime change. Today the county is a regional administrative unit without money and tasks, which is unable to fulfil its function as a result of the lack of sources. Besides its competence is limited by the irrationality that the county government is in equal relationship with settlement governments. Today there is no efficiently operating constitutional medium-size administrative unit. Small regions came into being as separate companions of settlements and are only ruled by decree. They have no choosen corps, they only have a work corporation including delegates of the settlements. Their sizes are different their content changes often either based on the interests of certain settlements.

${ }^{29}$ Today the role of a county is partially devolved to planning-statistical regions by the government, but they don't own constitutional rights.

${ }^{30}$ Nagy T. 2005: Zala megye határon átnyúló szubregionális együttmüködései. Diploma Dolgozat (Trans-border subregional co-operations of Zala county. Thesis Work) pp. 20-21, pp. 51.

${ }^{31}$ Litter N. 2005: Elöterjesztés Nagykanizsa Megyei Jogú Város Közgyülésének 2005 szeptember 27.i ülésére. Napirend: Dráva-Mura Eurorégió Kht. Müködése. (Proposal to the General Assembly of Nagykanizsa City to the meeting of September $27^{\text {th }} 2005$. Daily routine: The operation of the Dráva-Mura Euroregion Public Company), Date of download: 27.02.2008.

${ }^{32}$ Füzi A. 2007: Egy hátrányos helyzetü kistérség munkaerö-piaci helyzetképe. TDK dolgozat NyugatMagyarországi Egyetem. (The labor-market situation of a backward small region. TDK competition-work University of West-Hungary), pp. 74 .

${ }^{33}$ The marketing strategy of integrated economy-innovation in the "Muránia-region". PHARE Experimental Small Project Fund. 2003. Hungary-Croatia HU. Aquaprofit Technological Advisory and Investment Public Company 2005. December. 